\title{
Lapindo Embankment Security Monitoring System Based on IoT
}

\author{
Shazana Dhiya Ayuni ${ }^{1}$, Syamsudduha Syahrorini ${ }^{2}$, Jamaaluddin ${ }^{3}$ \\ ${ }^{1,2,3}$ Program Studi Teknik Elektro, Fakultas Sains dan Teknologi, Universitas Muhammadiyah Sidoarjo . \\ E-mail: shazana@umsida.ac.id, syahrorini@umsida.ac.id, jamaaluddin@umsida.ac.id
}

\begin{abstract}
Natural gas drilling leaks in the Sidoarjo district produced the Lapindo mudflow. Despite the construction of a dike, the mudflow still gave an impact on the residential. Because the embankment has been leaking frequently in recent years that causing discomfort to those who live near it. Using a network of sensors spread across the dangerous area of the embankment, this research will monitor the vibration and overflow of the Lapindo embankment mud, which will subsequently be communicated to a smartphone via the Blynk app. The Arduino UNO microcontroller processes the sensors, which include accelerometers for vibration detection and ultrasonic sensors for mudflow monitoring. The monitoring system application will use the ESP8266 to deliver a danger signal to the smartphone if a disaster occurs. If the vibrations and mudflow reach the embankment's maximum limit, the application will display a warning message. In order for residents to feel safe, this monitoring technology must be available.
\end{abstract}

Keywords: Monitoring, Lapindo Embankment, IoT

\section{INTRODUCTION}

Natural gas drilling in Sidoarjo, East Java, has caused the Lapindo mudflow since May 26th, 2006. PT. Lapindo Brantas is responsible for the natural gas drilling leakage[1]. The mud control center in Sidoarjo (PPLS/ Pusat Pengendalian Lumpur Sidoarjo) was established as a disaster management organization for the Lapindo mudflows. However, other villages refused to evacuate, despite the fact that the mud had already reached their houses[2]. This disaster has had a significant influence on their economic situation as well as their mental health. Houses, roads, buildings, public facilities, and work facilities were all damaged. According to the study, In terms of social consequences, the victims and survivors lose their possession such as the employment, access to land, and significant social changes [3]. Siring, Jatirejo, Renokenongo, Kedungbendo, Ketapang, Gempolsari, Mindi, Pejarakan, Kedungcangkring, Besuki, and Glagaharum are among the villages that have sunk partly or entirely up to 2017. The villages were sunk for a variety of reasons, including uncontrolled mudflow volumes, soil fractures, land subsidence, and even gas bursts, which put the residents' houses in danger[4][5]. geographically, the Sidoarjo regency is not in a disaster-prone area that could endanger the population's safety. Because of the Lapindo mudflow, changes in land use and spatial organization were mandated[6]. The Lapindo mudflow is still active, thus the Mud Control Center Sidoarjo (PPLS) is planning to erect a dike on the east side of the main dike to prevent mud from spreading across the area[7]. Muddy water, wet mud, dry mud, and mud that has begun to dry out are the four types of mudflow in Lapindo. The wet mud has a great deal of potential to cause embankment damage [8].

In reservoir structure, real-time technology based on wireless sensor network technology was developed in South Korea. As a result of the application, it was revealed that volumetric water content changes in line with changes in the embankment body's landslide [9]. Forest fire monitoring instrument, on the other hand, utilizes an Arduino as a microcontroller with temperature, fire, and heat sensors. IoT (Internet of Things) was used to send the data sensor. Other disaster monitoring systems are also available [10][11]. A study suggests using a smartphone application to provide real-time flood information in Jakarta [12]. There is also an earthquake and 
flood warning system that uses ultrasonic and accelerometer sensors. The application then sends crisis alerts and photographs to a defined Telegram account, which anyone with the app installed on their phone or computer can access [13]. In a different study, DHT22, MQ-135, and HY-SRF05 sensors were used to create a smart chicken cage monitoring system that could be controlled by smartphone using IoT. The output of the three sensors above, processed with the NodemCu ESP8266, will be shown on an LCD and a smartphone using the Blynk App[14][15]. However, there is a monitoring device that uses an ultrasonic sensor to manage chemical percol fluid[16]. Our team developed a monitoring system for the Lapindo mudflow based on past research and the case.

In this study, a waterproof ultrasonic and accelerometer sensor was used to detect vibration and mud overflow. As a result, employing a wireless sensor network spread over a number of dike-prone spots to monitor the embankments for vibration and overflow of the lapindo puddle, data is sent to a smartphone via Blynk[17]. When an accident occurs, the system monitoring application will issue a warning and send a message to the user's smartphone. As a result, the existence of this monitoring technology can give citizens a sense of security that we can monitor the vibration.

\section{METHOD}

This research's flowchart is divided into two parts: hardware and software system design. In hardware system design, we create an Arduino configuration for each sensor and calibrate it to ensure that it functions properly. The Arduino Uno R3, an accelerometer, and an ultrasonic sensor are used. We plan collection data with a scheduling mechanism for data transmission through the smartphone or server node in software system design. In Blynk, you can also plan GUI system design. Before we install in the embankment, all of this system design will be integrated and tested in various locations. The first developing a software system is to create a graphical user interface that is user-friendly and simple to comprehend for people from all walks of life. As a result of the development of embankment security monitoring, it will be more successful in preventing any accident that could endanger citizens' lives.

The embankment safety monitoring system is implemented using a hardware system design that includes a microcontroller Arduino uno rev 3, accelerometer sensor, ultrasonic sensor, and ESP8266 to transmit data from node sensors to the server node. The solar panels are also used to power the hardware, which includes a solar charge controller and a 12v 7Ah battery. The Blynk application is used to instruct Arduino to sense the sensor and show it as a graphic user interface on a smartphone utilizing software system design. Here is how it is explained in Figure 1:

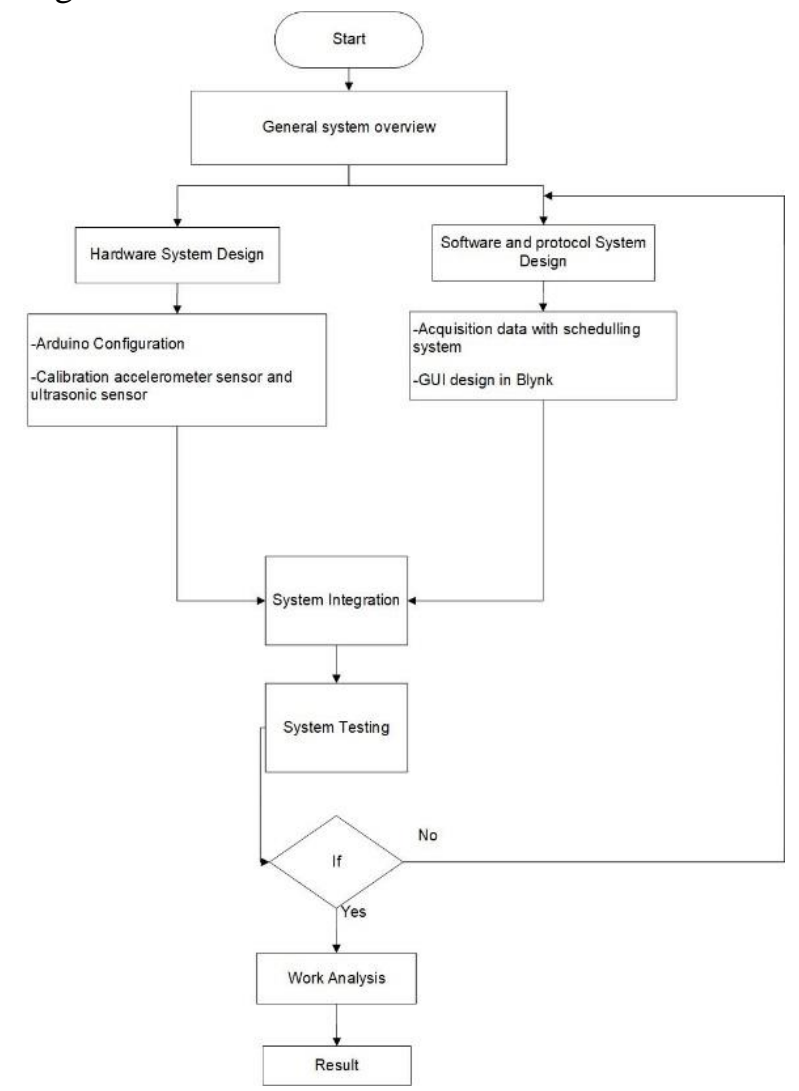

Figure 1. Flowchart System

Figure 2 shows a test scenario for a monitoring system. We observe the position of the embankment, as well as its construction and current situation, before beginning this study. Increased sludge volume causes several dangers, including subsidence and leaks. The system test 
scenario is to send data from a node sensor to a server, which in this case is a smartphone. Microcontroller, accelerometer, and ultrasonic sensor are all part of the node sensor. Testing system that uses a data acquisition system that is scheduled and collects data from a sensor at different times. However, it is possible to watch the condition on the embankment in real time. We used two node sensors in the system test scenario, each at a distance of 10 meters. The graph will next be tested to see how it looks when a heavy vehicle passes with any vibration caused by the embankment collapsing. We also conducted tests on the highway to determine the characteristics of the accelerometer in response to various vibration inputs.

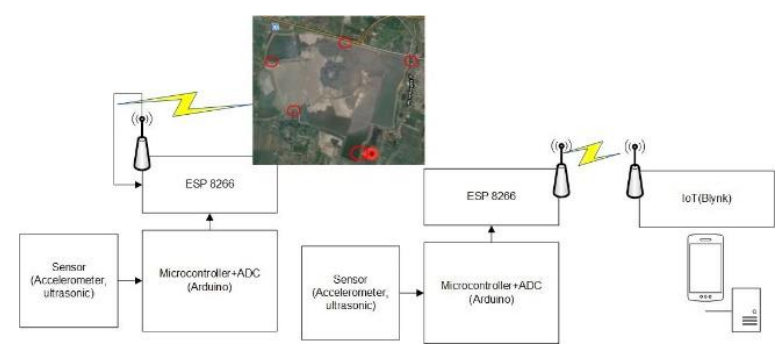

Figure 2. Testing System

Prior to testing on the Lapindo embankment, we replicate by building an artificial embankment with round up the sand. The artificial embankment will be built to resemble a broken embankment in order to determine how many grades will be displayed on the monitoring system. It will be detected by an accelerometer, so we are familiar with a variety of grades with varying levels of vibration.

\section{RESULT AND DISCUSSION}

There are two types of testing systems: hardware and software testing. Accelerometer and ultrasonic sensor testing are used for hardware testing. The ultrasonic sensor calibration is the first test. The ultrasonic sensor in this gadget is used to check the water in mud puddles on the Lapindo embankment. During the rainy season, mud water frequently overflows the homes of the locals. As a result, sensor calibration is necessary to ensure that a sensor is operating properly and that the error rate is known.

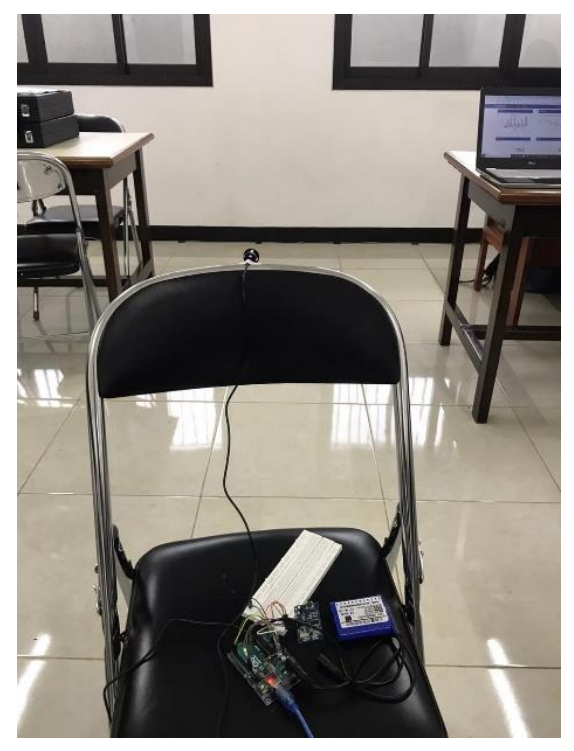

Figure 3. Calibration Ultrasonic sensor

We conducted the experiment in the electrical lab, placing sensors on the chair, and measuring the distance by moving the chair $50 \mathrm{~cm}$ at the real distance. The sensor then uses Thing Speak to deliver distance data to IoT application through the web and smartphone. The ultrasonic sensor will generate an error rate by comparing the actual distance with the distance in the application. The measurements are 50 centimeters, 100 centimeters, 150 centimeters, 200 centimeters, 250 centimeters, 300 centimeters, 350 centimeters, 400 centimeters, 450 centimeters, and 500 centimeters.

Table 1. Ultrasonic Calibration Data

\begin{tabular}{|c|c|c|c|}
\hline No. & $\begin{array}{c}\text { Actual } \\
\text { Distance } \\
(\mathrm{cm})\end{array}$ & $\begin{array}{c}\text { Application } \\
\text { Distance } \\
(\mathrm{cm})\end{array}$ & $\begin{array}{c}\text { Error rate } \\
(\%)\end{array}$ \\
\hline 1 & 50 & 45 & 10 \\
\hline 2 & 100 & 98 & 2 \\
\hline 3 & 150 & 145 & 3.333333 \\
\hline 4 & 200 & 196 & 2 \\
\hline 5 & 250 & 251 & -0.4 \\
\hline 6 & 300 & 295 & 1.666667 \\
\hline 7 & 350 & 349 & 0.285714 \\
\hline 8 & 400 & 397 & 0.75 \\
\hline
\end{tabular}




\begin{tabular}{|c|c|c|c|}
\hline 9 & 450 & 453 & -0.66667 \\
\hline 10 & 500 & 498 & 0.4 \\
\hline \multicolumn{3}{|c|}{ Total } & 19.36905 \\
\hline \multicolumn{3}{|c|}{ Avarage error rate } & 1,94 \\
\hline
\end{tabular}

The average error rate in Table 1 is 1.94 percent, which can be influenced by uneven and flat surfaces in the lab room, such as walls and windows on the right and left sides, which cause the ultrasonic sensor to pick up waves reflected from the wall. In contrast to actual distance. However, as the distance between the two points increases, the error rate decreases. According to the datasheet for the DC $5 \mathrm{~V}$ distance waterproof sensor ultrasonic module, which may be used indoors or outdoors, the greatest distance this ultrasonic sensor can capture is $5 \mathrm{~m}$ or $500 \mathrm{~cm}$.

The ultrasonic sensor works properly after calibration. The ultrasonic sensor will then be directly tested against the water overflow. The test was conducted at UMSIDA campus 2, namely in the bathroom, by slowly filling the bath with water and monitoring the change in the output value produced by the ultrasonic sensor as shown in the Blynk application. This can be seen in Figure 5 as follows.

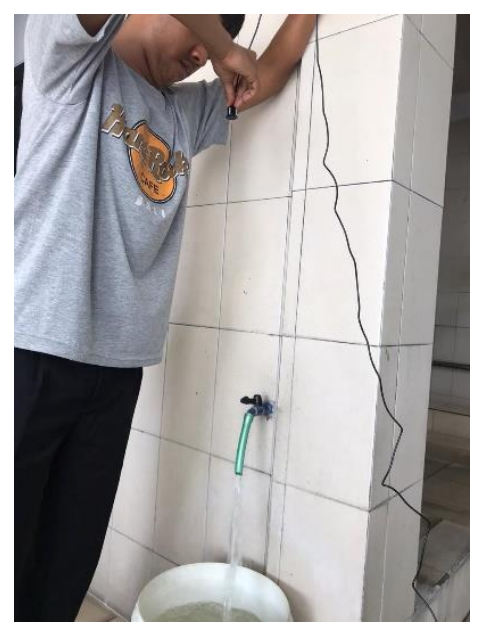

Figure 4. ultrasonic sensor testing in a water tank

Firstly, the water tank is emptied, then the water tap is turned on to simulate the embankment overflowing with mud. The goal of this test is to see if the ultrasonic sensor can detect water overflow, and if so, the Blynk program can monitor it and identify an overflow of water, as shown in Figure 4 below, with a notification of Beware of Overflowing Water. If the water continues to overflow for an extended period of time, a continuous notification will show, and the smartphone will vibrate to alert the person.

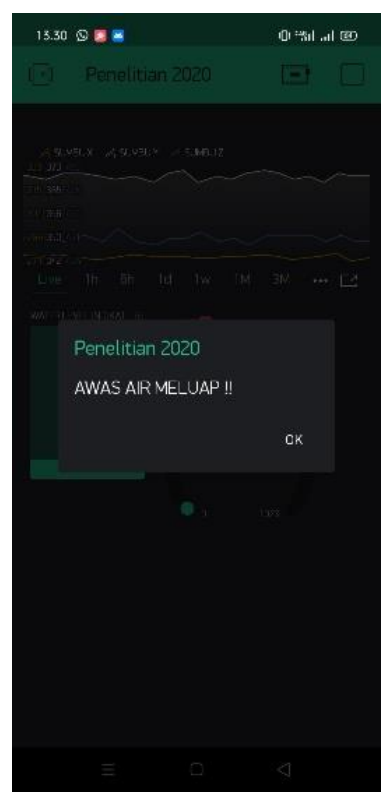

Figure 5. Blynk Application Monitor Display When Water Overflows

Next, the accelerometer sensor will be tested. The vibration on the embankment is detected and monitored using an accelerometer sensor. Before an accelerometer sensor is installed, it is calibrated and tested for various types of vibration conditions. The MMA 7361 accelerometer sensor has three axes: $\mathrm{x}, \mathrm{y}$, and $\mathrm{z}$. As a result, it is necessary to know the value of each axis under varied vibration and position situations. Before that, the sensor must be calibrated to ensure that it can detect vibrations in all three axes (x, y, and $\mathrm{z}$ ). The sensor, which is an accelerometer, is then tilted along three axes to determine the peak value of each axis when it reaches a crisis point.

As the result, it can become a standard value to be installed in the accelerometer sensor programming on the Arduino. There are 4 test conditions are carried out to get the peak value of each triple axis. Condition 1 is a condition 
accelerometer sensor is placed on the table and normally without tilt.

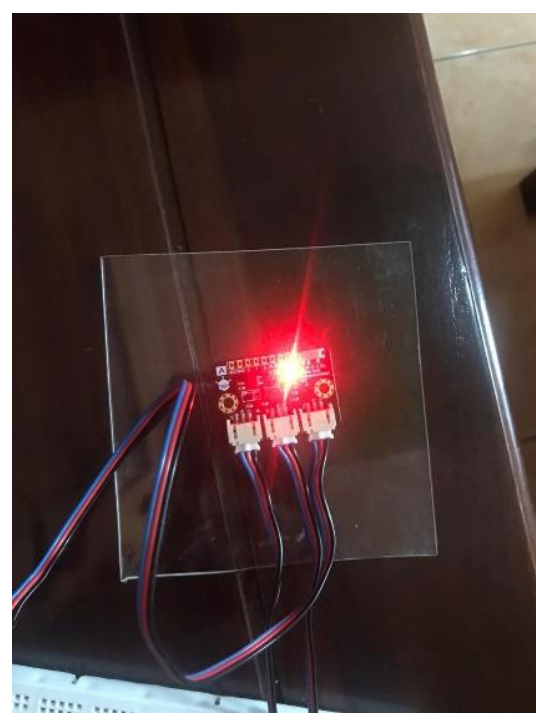

Figure 6. Condition 1 of Accelerometer Sensor

The visual on the accelerometer sensor that reads in MATLAB is a continuous graph, as seen in Figure 6. The $\mathrm{x}$ and $\mathrm{y}$ axes are combined into one axis, and the $\mathrm{z}$-axis is elevated. Where the $\mathrm{x}$ and $y$ axes have normal values of 350 and the $z-$ axis has a value of 450 .

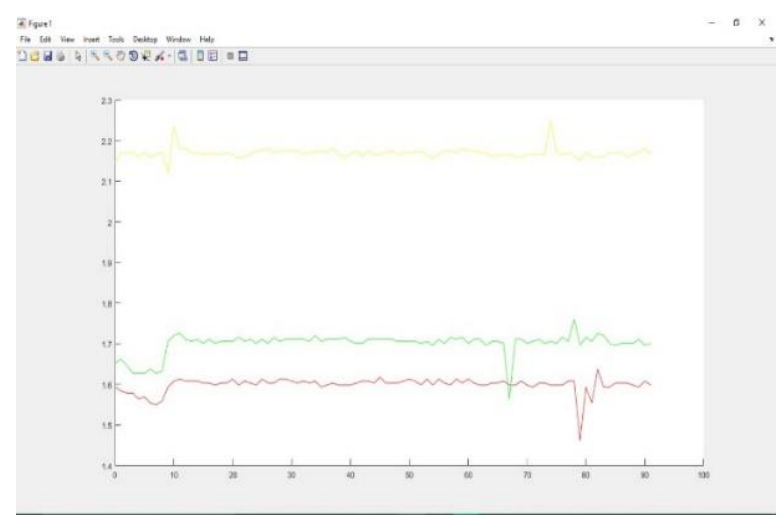

Figure 7. Graphic of Condition 1 Accelerometer Sensor

The next test is condition 2, which is tilted on the $\mathrm{z}$ axis, while conditions 3 and 4 are inclined on the $\mathrm{x}$ and $\mathrm{y}$ axes, respectively. So that, the peak value on each axis is attained.

Table 2. Reference Value

\begin{tabular}{|l|l|}
\hline Axis & Reference Value \\
\hline Axis $\mathrm{X}$ & $250>\mathrm{x}>450$ \\
\hline Axis $\mathrm{Y}$ & $220>\mathrm{y}>450$ \\
\hline Axis $\mathrm{Z}$ & $280>\mathrm{z}>600$ \\
\hline
\end{tabular}

As a result, the above reference value is utilized as input in the program for the "Danger" sign notification in the Blynk application.

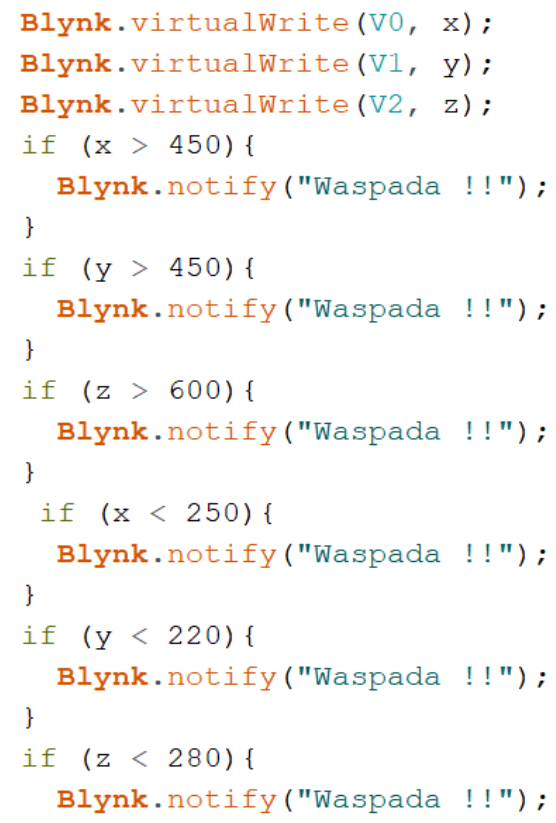

Figure 8. Arduino Program

The next accelerometer sensor test will take place on the road. The purpose of this experiment is to determine the vibration characteristics of vehicle passing. When several heavy vehicles pass, the embankment to repair the damaged embankment construction.

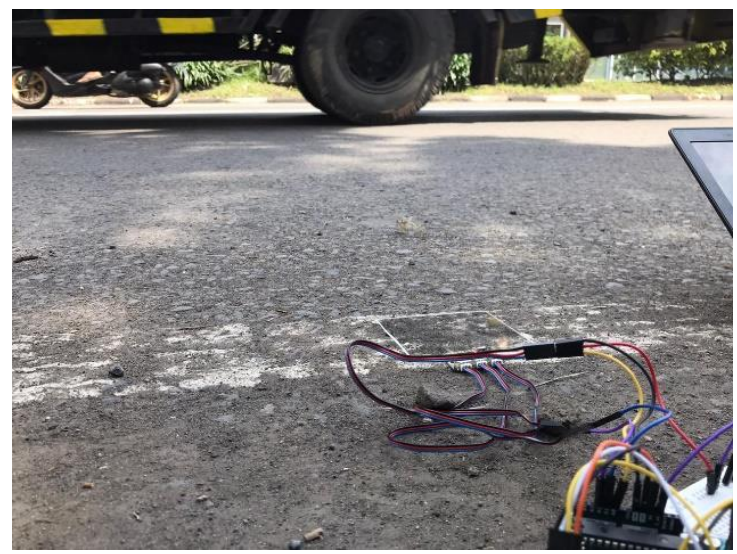

Figure 9. Accelerometer Sensor Testing on the Highway

The test was carried out for two hours and conducted in front of UMSIDA campus 2 . 
Then, it is monitored using MATLAB to display a graph of the detected vibration to find out the characteristics of the ultrasonic sensor. Then, the average graph model is obtained if the ultrasonic sensor detects vibrations from vehicle. Even though the vehicles that pass are varied, from two-wheeled vehicles, four-wheeled vehicles to heavily loaded vehicles, they show similar characteristics. The following is a MATLAB graph of the results of testing the accelerometer sensor on the highway.

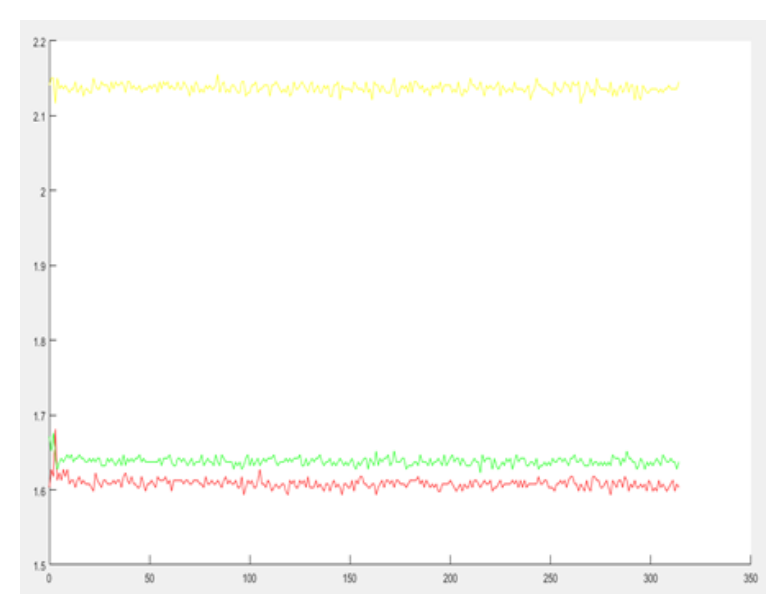

Figure 10. MATLAB Graphs Accelerometer Sensor

The $\mathrm{z}$ axis is shown in yellow, while the $\mathrm{x}$ and $\mathrm{y}$ axes are shown in green and red. Figure 10 shows that as a vehicle passes, even if it is passing a heavily loaded vehicle with few wheels, the graph tends to remain constant. The accelerometer sensor is connected to a microphone in the hopes of detecting vibrations caused by passing vehicles.

Before the accelerometer sensor is put on the Lapindo's cradle. Firstly, we simulate the artificial embankment in order to determine the values of the $\mathrm{x}, \mathrm{y}$ and $\mathrm{z}$ axis under various scenarios. When the accelerometer sensor detects an embankment that has collapsed due to a small landslide, the test setting is activated. The embankment simulation consists of a $60 \mathrm{~cm}$ sand pile and an accelerometer sensor that has been given mica and is placed on top of the sand pile, after which the sand is intentionally lowered, causing the accelerometer sensor to fall. This test setting is made to get the reference value entered in the programming when the embankment is broken and then sends a notification on the smartphone via the Blynk application. Each axis has its own crisis point for its emergency situation. This value will be the reference for the condition of the embankment when it breaks. The embankment collapsed due to the most recent condition in January 2021, causing puddles to flood into the houses of the people. Not to mention when this occurs due to excessive rains.

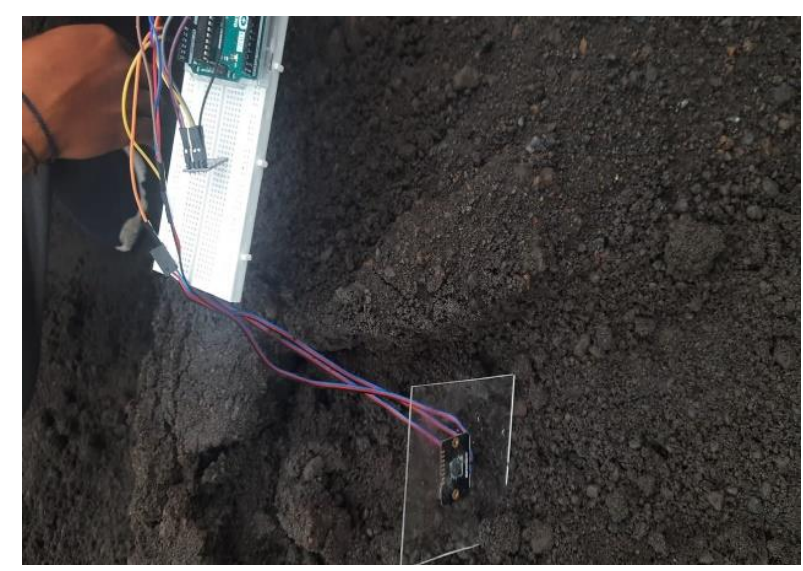

Figure 11. Accelerometer Sensor Testing

The position of the accelerometer sensor has fallen due to a landslide, as shown in Figure 11. When the accelerometer sensor detects vehicle vibrations, the graph shows the conditions are different. The graph will have a sharp fall, and the decrease in value will be obvious. Then, on each $\mathrm{x}, \mathrm{y}$ and $\mathrm{z}$ axis, we take the peak value of the abnormal situation as previously described.

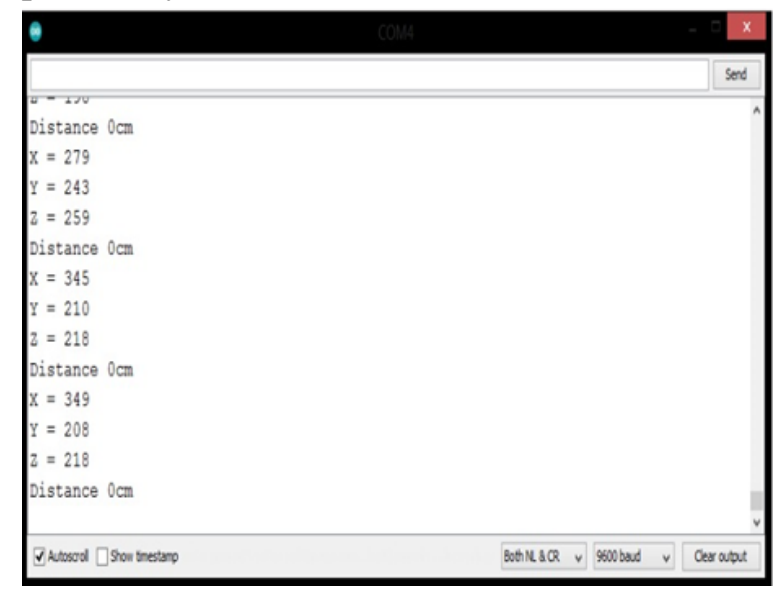

Figure 12. Accelerometer Sensor Monitor Serial Abnormal Condition 
Figure 12 above is the result of a serial monitor for the values of the $\mathrm{x}, \mathrm{y}$ and $\mathrm{z}$ axes of the accelerometer sensor when the artificial embankment was accidentally unloaded. Where the peak value for this condition is 279-349 on the $x$-axis, the critical value on the $y$-axis is 208243 on the $y$-axis, and the z-axis is 259 . To determine the graph model of each value, a graph is created using the data above, as shown in Figure 5.9. When the accelerometer sensor detects an artificial embankment avalanche, an axis is generated.

In addition to abnormal conditions, a normal condition test is also carried out on the accelerometer sensor on the artificial embankment. In order to know the values for each axis when nothing happens to the artificial embankment.

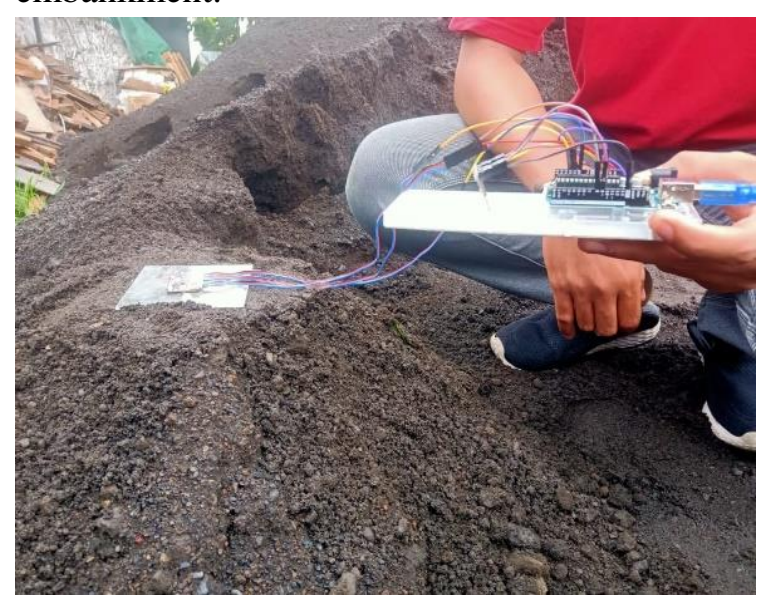

Figure 13. Normal Condition of Accelerometer Sensor on Artificial Dike

Figure 13 shows the condition of the accelerometer sensor before the artificial embankment was deliberately removed to determine the normal value of the sensor.

When Lapindo is covered, the following test will be performed. It's the same as in the artificial embankment, but we were examining to see if the vibration and the resulting graph are similar so that the reference value is same. The first is that the sensor receives vibrations in the form of footsteps and passing motor vehicles, as shown on Figure 14, which is used to distinguish between normal and abnormal embankment conditions. The result is then displayed in
MATLAB as a graph, where it can be seen that the characteristics of the graph when a car passes by and the footsteps are remarkably similar. But it is not too dissimilar from the previous test on artificial embankment.

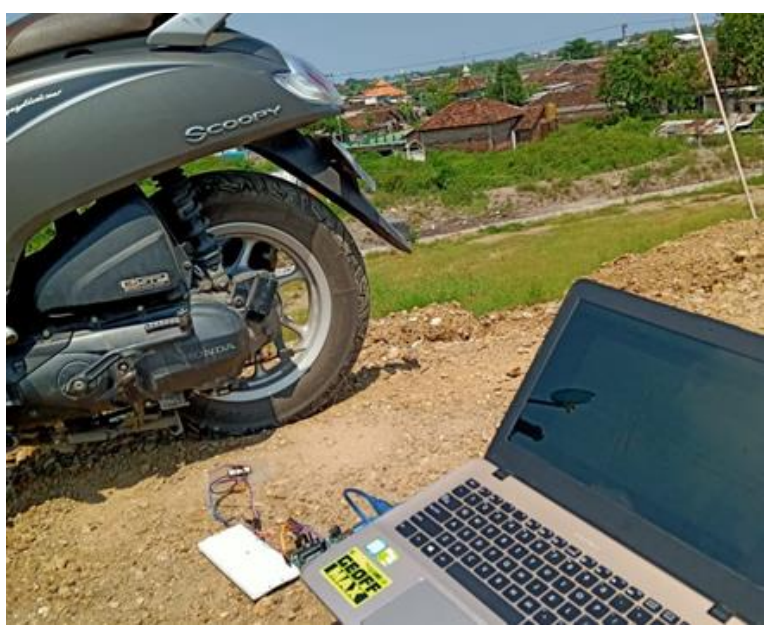

Figure 14. Accelerometer Testing at the Lapindo Embankment

The Lapindo embankment is then deliberately launched along with the sensor in the next test. The graph is then viewed in MATLAB, and the value is displayed on an Arduino IDE monitor series. So that the reference value can be entered into the program to generate a "Danger" notification in the Blynk app. This test can be seen in Figure 15.

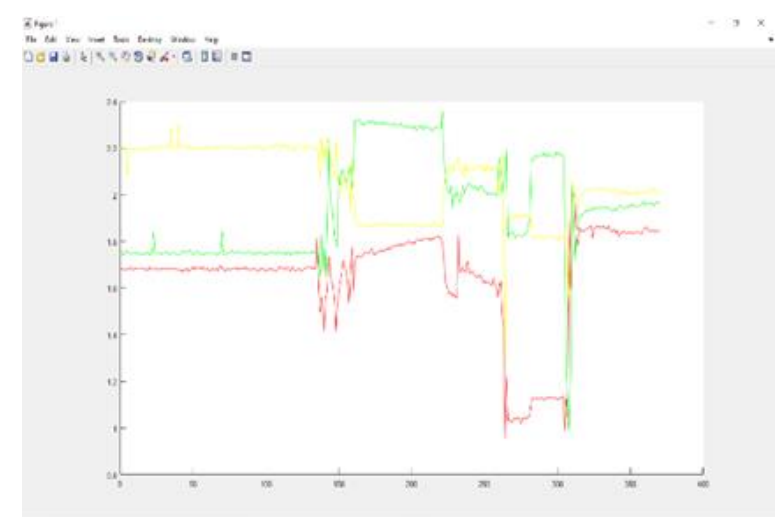

Figure 15. MATLAB Accelerometer Falling Graph

The internet connection will be tested next when the dike is broken. Because the sensor data provided to the smartphone via the Blynk app has to be connected to the internet. As a result, we ensure that the internet network is 
stable and that sensor data can be sent. In Indonesia, tests were conducted in a number of locations.

The test was conducted at the Perum Griya Candi Asri Sidoarjo, a distance of 5.9 kilometers from the location where the monitoring equipment was installed on the Lapindo embankment, and the application was still working. The real me Narzo20 smartphone was used in the experiment. The program can be properly connected in this test.

The next test was conducted in Surabaya, 36.2 kilometers from where the monitoring equipment was installed on Lapindo embankment. The Samsung Galaxy A2 core smartphone was used for testing. The program can be properly connected in this test.

The Oppo F5Youth smartphone was used for the next IoT test when monitoring equipment placed on the Lapindo Sidoarjo embankment. The application test location is in Bekasi, West Java, at a distance of 769 kilometers, where the application may be correctly connected.

The next IoT test uses a Samsung Galaxy S4 smartphone in Riau Sumatra at a distance of 2029 miles. The app can also be correctly connected. It is stated in a table below of all the IoT tests above

Table 3. IoT Testing

\begin{tabular}{|l|l|l|l|}
\hline No & \multicolumn{1}{|c|}{$\begin{array}{c}\text { Smartphone } \\
\text { Type }\end{array}$} & Distance & Trial \\
\hline 1 & $\begin{array}{l}\text { Real Me Narzo } \\
20\end{array}$ & $5,9 \mathrm{~km}$ & Success \\
\hline 2 & $\begin{array}{l}\text { Samsung } \\
\text { Galaxy A2 Core }\end{array}$ & $36,2 \mathrm{~km}$ & Success \\
\hline 3 & Oppo F5 Youth & $769 \mathrm{~km}$ & Success \\
\hline 4 & $\begin{array}{l}\text { Samsung } \\
\text { Galaxy S4 }\end{array}$ & $2029 \mathrm{~km}$ & Success \\
\hline
\end{tabular}

The following is a monitor display on a smartphone that shows a graphic from the accelerometer sensor and also the water level from the ultrasonic sensor.

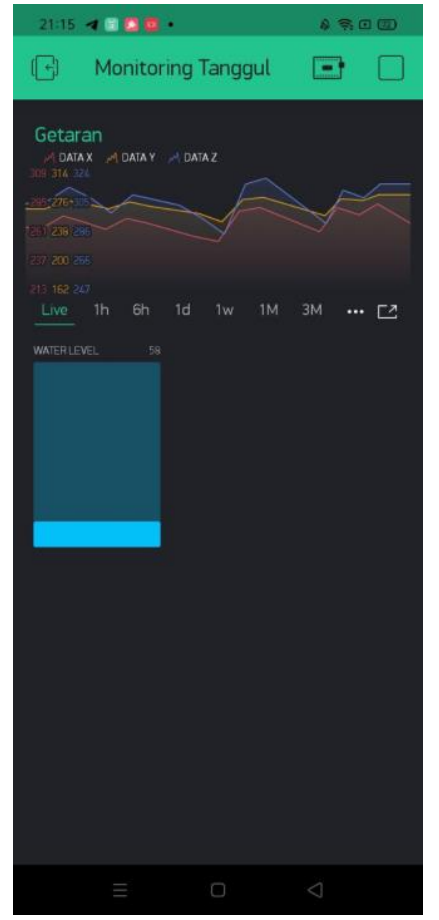

Figure 16. Blynk Application Views

\section{CONCLUSION}

The accelerometer sensor MMA7361 works well for vibration detection because it is very sensitive to any vibration and has three axes that can detect vibration in all directions. As a result, the sensor is put to the test in order to ascertain the reference value. If there is a strong vibration, this sensor will notice it immediately. Furthermore, for Ultrasonic sensors, the waterproof type must be utilized, and the error rate is 1,74 percent. In this study, an accelerometer and an ultrasonic sensor were used to monitor the embankment, and the data was sent to Blynk using an Arduino UNO and an ESP8266. It may also send to Riau which is 2029 kilometers away. The local residents have been socialized and used the application.

\section{ACKNOWLEDGMENTS}

This research was funded by the Muhammadiyah University of Sidoarjo as the institution's applied research program 2020/2021 


\section{REFERENCE}

[1] M. I. Agustina, "Dampak bencana lumpur lapindo terhadap kehidupan sosial ekonomi masyarakat (Studi kasus pada masyarakat desa renokenongo kecamatan porong kabupaten sidoarjo).” Universitas Negeri Malang, 2010.

[2] R. Padawangi, "Muddy resistance: Community empowerment in mudflow disaster governance in Porong, Sidoarjo, Indonesia," in Disaster Governance in Urbanising Asia, Springer, 2016, pp. 61-84.

[3] L. S. Palupi, "Did socioeconomic status influence psychological preparedness for potential disaster of resident around lapindo mud disaster," in IOP Conference Series: Earth and Environmental Science, 2021, vol. 698, no. 1, p. 12012.

[4] J. Ekawati, "Kebertahanan Kultural dan Religi di Area Permukiman Terdampak Bencana Lumpur Lapindo Sidoarjo, Jawa Timur," Sabda J. Kaji. Kebud., vol. 13, no. 2, pp. 122-134, 2018.

[5] J. Ekawati, G. Hardiman, and E. E. Pandelaki, "Analysis of GIS-Based Disaster Risk and Land Use Changes in The Impacted Area of Mudflow Disaster Lapindo," in IOP Conference Series: Earth and Environmental Science, 2020, vol. 409, no. 1, p. 12032.

[6] R. Rismayudha, "Tinjauan Yuridis Kedudukan Kasus Lumpur Lapindo dan Uang Pengganti Bagi Korban Lumpur Lapindo Ditinjau Dari Peraturan Perundang-Undangan.” Universitas Kristen Maranatha, 2015.

[7] B. P. L. Sidoarjo, "No Title," 2016. http://sda.pu.go.id/pusat/ppls/.

[8] M. N. Hamsyah and G. S. Utami, "Perbaikan Tanah Lunak Kombinasi Preloading dengan Prefabricated Vertical Drain Studi Kasus Rencana Tanggul Lapindo Porong," J. Tek. Sipil, vol. 1, no. 2, pp. 95-101, 2021.

[9] C. Yoo, I. Kim, S. Lee, J. Hwang, and S. Baek, "Basic study on monitoring system of reservoir and leeve using wireless sensor network," $J$. Korean Geoenvironmental Soc., vol. 19, no. 1, pp. 25-30, 2018.

[10] D. Sasmoko and A. Mahendra, "Rancang Bangun Sistem Pendeteksi Kebakaran Berbasis IOT dan SMS Gateway Menggunakan Arduino," Simetris J. Tek. Mesin, Elektro Dan Ilmu Komput., vol. 8, no. 2, pp. 469-476, 2017.

[11] M. I. Mahali, "Smart door locks based on internet of things concept with mobile backend as a service," Elinvo (Electronics, Informatics, Vocat. Educ., vol. 1, no. 3, pp. 171-181, 2016.

[12] V. L. P. Anta, I. A. Liestyo, and H. L. H. S. Warnars, "Mobile Application for flood disaster in Jakarta," in 2021 International Conference on Artificial Intelligence and Smart Systems (ICAIS), 2021, pp. 506-510.

[13] A. Z. Shukor et al., "Investigation of a New
Earthquake and Flood Alert System," J. Telecommun. Electron. Comput. Eng., vol. 10, no. 2-2, pp. 11-17, 2018.

[14] S. Syahrorini, A. Rifai, D. H. R. Saputra, and A. Ahfas, "Design smart chicken cage based on internet of things," in IOP Conference Series: Earth and Environmental Science, 2020, vol. 519, no. 1, p. 12014.

[15] T. H. A. Cahyono and E. A. Suprayitno, "Alat Ukur Berat Badan, Tinggi Badan dan Suhu Badan di Posyandu Berbasis Android," ELINVO (Electronics, Informatics, Vocat. Educ., vol. 3, no. 1, pp. 31-38, 2018.

[16] A. Ahfas, D. Hadidjaja, S. Syahrorini, and J. Jamaaluddin, "Implementation of ultrasonic sensor as a chemical percol fluid level control based on Atmega 16," in IOP Conference Series: Materials Science and Engineering, 2021, vol. 1098, no. 4, p. 42046.

[17] E. A. S. MT and R. D. M. Kom, "Otomasi Sistem Hidroponik DFT (Deep Flow Technique) Berbasis Arduino Android dengan Memanfaatkan Panel Surya sebagai Energi Alternatif," ELINVO (Electronics, Informatics, Vocat. Educ., vol. 3, no. 2, pp. 30-37, 2018. 